\title{
Solution existence of general variational inequalities and coincidence points
}

\section{AlireZA AMINI-HARANDI and SZILÁRD LÁSZLÓ}

\section{ABSTRACT.}

In this paper, by using a simple technique, we obtain several existence results of the solutions for general variational inequalities of Stampacchia type. We also show, that the existence of a coincidence point of two mappings is equivalent to the existence of the solution of a particular general variational inequality of Stampacchia type. As applications several coincidence and fixed point results are obtained.

Acknowledgements. The first author was partially supported by a grant from IPM (No. 92470412). This work was supported by a grant of the Romanian Ministry of Education, CNCS - UEFISCDI, project number PN-II-RU-PD-2012-3 -0166.

\section{REFERENCES}

[1] Aussel, D. and Hadjisavvas, N., On quasimonotone variational inequalities, J. Optim. Theory Appl., 121 (2004), No. 2, 445-450

[2] Baiocchi, C. and Capelo, A., Variational and quasi-variational inequalities, Wiley, New York, (1984)

[3] Bensoussan, A. and Lions, J. L., Applications des inequations variationelles en control et stochastiques, Dunod, Paris, (1978)

[4] Bertsekas, D. P. and Gafni, E. M., Projection methods for variational inequalities with applications to the traffic assignment problem, Math. Prog. Study, 17 (1982), 139-159

[5] Dafermos, S., Exchange price equilibria and variational inequalities, Math. Programming, 46 (1990), 391-402

[6] Ferrentino, R., Variational inequalities and optimization problems, Appl. Math. Sci., 1 (2007), 2327-2343

[7] Fichera, G., Problemi elastostatici con vincoli unilaterali: il problema di Signorini con ambigue condizioni al contorno, Atti Accad. Naz. Lincei, Mem. Cl. Sci. Fis. Mat. Natur. Sez. la, 7 (8), (1963-1964), 91-140

[8] Kinderlehrer, D. and Stampacchia, G., An Introduction to Variational Inequalities and Their Applications, Academic Press, New York, 1980

[9] László, S., Some existence results of solutions for general variational inequalities, J. Optim. Theory Appl., 150 (2011), 425-443

[10] László, S., Existence of solutions of inverted variational inequalities, Carpathian J. Math., 28 (2012), 271-278

[11] Maugeri, A. and Raciti, F., On existence theorems for monotone and nonmonotone variational inequalities, Journal of Convex Analysis, 16 (2009), 899-911

[12] Noor, M. A., General variational inequalities, Appl. Math. Lett., 1 (1988), 119-121

[13] Rus, I. A., Petruşel, A. and Petruşel, G., Fixed Point Theory 1950-2000: Romanian Contributions, House of the Book of Science, Cluj-Napoca, 2002

[14] Salhi, N. and Taoudi, M. A., Existence of integrable solutions of an integral equation of Hammerstein type on an unbounded interval, Mediterr. J. Math., 9 (2012), 729-739

[15] Stampacchia, G., Formes bilineaires coercitives sur les ensembles convexes, C. R. Acad. Sci. Paris, Sr I. Math., 258 (1964), 4413-4416

[16] Takahashi, W. and Toyoda, M., Weak convergence theorems for nonexpansive mappings and monotone mappings, J. Optim. Theory Appl., 118 (2003), 417-428

Received: 21.02.2013; In revised form: 15.07.2013; Accepted: 30.07.2013

2010 Mathematics Subject Classification. 46A50, 47H04, 54A20, 58C07.

Key words and phrases. General variational inequality, coincidence point, $\alpha$-inverse strongly monotone operator, strict pseudocontractive mapping.

Corresponding author: Szilárd László; laszlosziszi@yahoo.com 
Department of Pure Mathematics

UNIVERSITY OF SHAHREKORD

SHAHREKORD 88186-34141, IRAN

SCHOOL OF MATHEMATICS

INSTITUTE FOR RESEARCH IN FUNDAMENTAL SCIENCES (IPM)

P.O. BOX:19395-5746 TEHERAN, IRAN

E-mail address: aminih_a@yahoo.com

Department of Mathematics

TECHNICAL UNIVERSITY OF CLUJ NAPOCA

Memorandumului 28, 400114 Cluj-Napoca, Romania

E-mail address: laszlosziszi@yahoo.com 